\title{
Evaluation of the Usefulness of GDH \& Toxin Test for the Diagnosis of Clostridioides difficile in a Tertiary Hospital in Seoul
}

\author{
Ho-Joong Joo ${ }^{1, *}$, Sang-Ha Kim ${ }^{2, *}$, Pil-Seung Kwon ${ }^{3, * *}$, Jae-Ki Ryu ${ }^{4, * *}$, Keun-Dol Yook ${ }^{5, * *}$, \\ Young-Bin $\mathrm{Yu}^{6, * *}$ and Young-Kwon Kim ${ }^{7, \dagger, * *}$ \\ ${ }^{I}$ Department of Laboratory Medicine, Samsung Medical Center, Seoul 06351, Korea \\ ${ }^{2}$ Department of Laboratory Medicine, Konyang University Hospital, Daejeon 35365, Korea \\ ${ }^{3}$ Department of Clinical Laboratory Science, Wonkwang Health Science University, Iksan 54538, Korea \\ ${ }^{4}$ Department of Biomedical Laboratory Science, College of Natural Science, \\ Gimcheon University, Gimcheon 39528, Korea \\ ${ }^{5}$ Department of Clinical Laboratory Science, Daejeon Health Institute of Technology, Daejeon 34504, Korea \\ ${ }^{6}$ Department of Biomedical Laboratory Science, College of Medical Sciences, \\ Konyang University, Daejeon 35365, Korea \\ ${ }^{7}$ Department of Health Sciences, The Graduate School of Konyang University, Daejeon 35365, Korea
}

\begin{abstract}
The purpose of this study was to evaluate GDH \& Toxin (GDT) tests for the identification of the presence of Clostridioides difficile (C. difficile) as well as to detect whether any toxin was present in the feces of patients suspected of diarrhea associated with C. difficile. Data related to the results of toxin and culture (TC) tests and GDT tests conducted on patients with diarrhea and suspected CDI between January 2017 and august 2018, positive test rates, patient ages and sexes, whether the patients were hospitalized, and turnaround time (TAT) were analyzed retrospectively. Of the 7,554 total tests conducted for CDI diagnosis, $1,010 \mathrm{TC}$ tests (14.9\%) were positive, while 92 GDT tests (12.0\%) were positive. Of these positive cases, $815(80.7 \%)$ identified through TC test and 80 (87\%) identified through GDT test were inpatients. also, among the patients with positive test results, 497 (49.2\%) diagnosed through TC test and 45 (48.9\%) diagnosed through GDT test were aged 61 years or older. The total time required to complete a TC test was 83.6 hours, while the time required for a GDT test was 11.2 hours, equating to an approximately three-day difference between the two tests. The detection of toxin-producing $C$. difficile is important in CDI diagnosis, but the commonly used Enzymeimmunoassay (EIA) toxin tests with low sensitivity result in delayed CDI diagnosis time. Therefore, primary screening tests for CDI diagnosis using the GDT method and secondary tests using additional methods are considered most effective.
\end{abstract}

Key Words: $C$. difficile, Toxigenic culture, AAD, CDI, ASM, GDH

\section{서 론}

Clostridioides (Clostridium) difficile은 무산소성 그람 양성
아포 형성 막대 균으로 접촉을 통한 분변-구강 경로를 통해 감염을 일으킨다. C. difficile은 병원 감염관리의 중 요한 대상 세균으로 분비하는 독소가 항생제 관련 설사 (antibiotic-associated diarrhea)와 위막성 대장염(pseudome

Received: June 11, 2020 / Revised: August 12, 2020 / Accepted: August 26, 2020

*Medical scientist, ${ }^{* *}$ Professor.

${ }^{\dagger}$ Corresponding author: Young-Kwon Kim. Department of Health Sciences, The Graduate School of Konyang University, 158 Gwanjeodong-ro, Seo-gu, Daejeon 35365, Korea.

Tel: +82-10-6436-3245, Fax: +82-42-543-6370, e-mail: ykkim3245@konyang.ac.kr

(C) The Korean Society for Biomedical Laboratory Sciences. All rights reserved.

@This is an Open Access article distributed under the terms of the Creative Commons Attribution Non-Commercial License (http://creativecommons.org/licenses/by-nc/3.0/) which permits unrestricted non-commercial use, distribution, and reproduction in any medium, provided the original work is properly cited. 
-mbranous colitis) 등을 일으키고, $C$. difficile이 존재하는 환 경에서 접촉을 통해 감염이 되기 때문에 세균 감염 병에 서 그 중요성이 점차 커지고 있다(Cho et al., 2010).

C. difficile 감염은 항생제 관련 설사의 원인 중 10 $20 \%$ 만을 차지하지만 항생제 치료와 관련된 장염의 경우 에는 대부분의 원인을 차지한다(Bartlett, 2002).

중증 $C$. difficile Infection (CDI)은 합병증을 일으키는데 증상이 대장에서 염증성 병변으로 특정되며 독성 거대 결 장(Toxic-megacolon), 장천공, 패혈증, 사망에 이르는 다양 한 합병증을 나타낸다(Lo Vecchio and Zacur, 2012).

C. difficile 관련 설사(C. difficile-associated diarrhea, CDAD) 의 원인은 항생제 사용으로 인해 장내 정상균 무리가 억 제되고, 접촉 감염된 C. difficile이 장내에서 군집화되면서 발생하는데, 항생제 사용량이 증가하거나 환자의 주위 환 경이 C. difficile의 아포로 오염된 경우 C. difficile 감염률 증가로 인한 $\mathrm{CDAD}$ 의 발생 빈도도 증가한다(Morris et al., 2002).

C. difficile의 주요 독성인자에는 장 독소(endotoxin)인 toxin $\mathrm{A}(T c d A, 308 \mathrm{kDa})$ 와 세포 내 독소(cytotoxin)인 toxin $\mathrm{B}(T c d B, 270 \mathrm{kDa})$ 가 있고, toxin $\mathrm{A}$ 와 $\mathrm{B}$ 는 세포 내에서 Guanosine triphosphate (GTP) 결합 단백에 작용하여 장관 세포의 cytoskeleton을 파괴하여 세포 손상을 유발하고, 염 증 및 세포 자멸사를 일으켜 질병을 일으키기 때문에 $C$. difficile의 동정과 C. difficile 독소 유무를 확인하는 것이 중요하다(Poxton et al., 2001; Kelly and LaMont , 2008). CDI 는 내원 기간 증가와 의료비를 증가시키게 되는데 $\mathrm{CDI}$ 발생 환자의 평균 내원 일수는 평균 3 7일이 증가하였 고, 의료비도 연간 최소 10 억에서 48 억 달러 소요되었다 (Dubberke and Olsen, 2012).

$\mathrm{CDI}$ 의 진단은 $\mathrm{GDH}$ 항원 검사 양성, Enzyme immunoassay (EIA) 독소 검사(toxin $\mathrm{A \& B}$ ) 양성, 세포 독소 중화시 험(cytotoxin neutralization assay) 양성 또는 핵산증폭 시험 (nucleic acid amplification test, NAAT) 양성인 경우에는 toxigenic C. difficile로 보고하며, 또한 $\mathrm{GDH}$ 항원 양성의 경우 다른 추가 검사들을 통해 반드시 결과가 확인되어야 하고, 만약 EIA 독소 검사 또는 세포 독소 중화시험 음성일 경 우는 핵산증폭 시험이나 배양 검사 중 한 가지 검사를 반 드시 시행해야 한다고 제안하고 있다(Surawicz et al., 2013).

본 연구에서는 서울 소재 2,000병상 이상의 일개 상급 종합병원에서 C. difficile 관련 설사가 의심되는 환자의 대 변에서 C. difficile 동정과 C. difficile 독소 생성 유무를 동 시에 확인할 수 있는 GDH \& Toxin 검사의 유용성을 평가
하여, 임상에서 $C$. difficile 감염관리 및 진단지침을 확립하 는 기초자료로 활용하는데 도움이 되고자 하였다.

\section{재료 및 방법}

\section{임상 검체}

2017년 1월 1일부터 2018년 8월까지 서울 소재 2,000병 상 이상 일개 상급종합병원에서 $C$. difficile 관련 설사가 의심되는 환자의 $C$. difficile infection $(\mathrm{CDI})$ 진단을 위해 독 소와 배양 검사, $\mathrm{GDH} \&$ Toxin 검사로 의뢰된 총 7,554건 을 대상으로 연구를 실시하였다.

\section{C. difficile 독소와 배양 검사}

Enzyme immunoassay (EIA): Free toxins A\& B 검출 독소 검사는 RIDASCREEN (R-Biopharm, Darmstadt, Germany) 시 약을 자동 효소 면역 분석기인 GEMINI (STRATEC Biomedical, Birkenfeld, Germany)를 사용해 검체 내 C. difficile 독소를 분석하였다. 검사 방법은 C. difficile의 항독소 항 체가 코팅되어 있는 마이크로 플레이트에(microplate)에 검체를 분주하여 반응시킨 후 발색시켜, 발색된 검체의 흡광도를 통해 C. difficile 독소의 양을 측정하였다. 결과 는 흡광도를 측정하여 양성(positive), 음성(negative), 판정 보류(equivocal)로 판단하였다.

Chrom ID C. difficile agar: C. difficile의 배양 검체를 Chrom ID C. difficile agar plate (BioMérieux, Marcy l'Etoile, France) 배지에 획선 접종하고, $3{ }^{\circ} \mathrm{C}$ 무산소 환경에서 48 시 간 배양한 후 회색 혹은 검은색의 불규칙한 경계를 가진 집락을 도말 후 그람염색을 하여 그람 양성 막대균을 확 인하고, 집락과 그람염색 결과가 일치하는 경우 C. difficile 로 동정하기 위하여 질량분석기(MALDI-TOF: VITEK-MS) 로 C. difficile을 확인 동정하였다.

Nucleic acid amplification assay (NAAT): Chrom ID $C$. difficile agar에서 자란 C. difficile의 의심스러운 회색 혹은 검은색의 집락을 자동 DNA 추출 장비인 MagNA Pure 96 kit (Roche Diagnostics, Mannheim, Germany)를 사용하여 제 조사의 지침에 따라 $\mathrm{DNA}$ 를 추출하였다. 추출된 $\mathrm{DNA}$ 와 제조사 물질 triose phosphate isomerase (tpi; a C. difficile specific housekeeping gene $230 \mathrm{bp}$ )와 toxin A gene (tcdA: NK2 \& NK3 251 bp)과 toxin B gene (tcdB: NK104 \& NK105 203 bp)의 프라이머를 이용하여 핵산을 증폭시킨 후 전기 
Table 1. Comparison of monthly positive rate distribution for toxin test, culture test and NAAT test of $C$. difficile

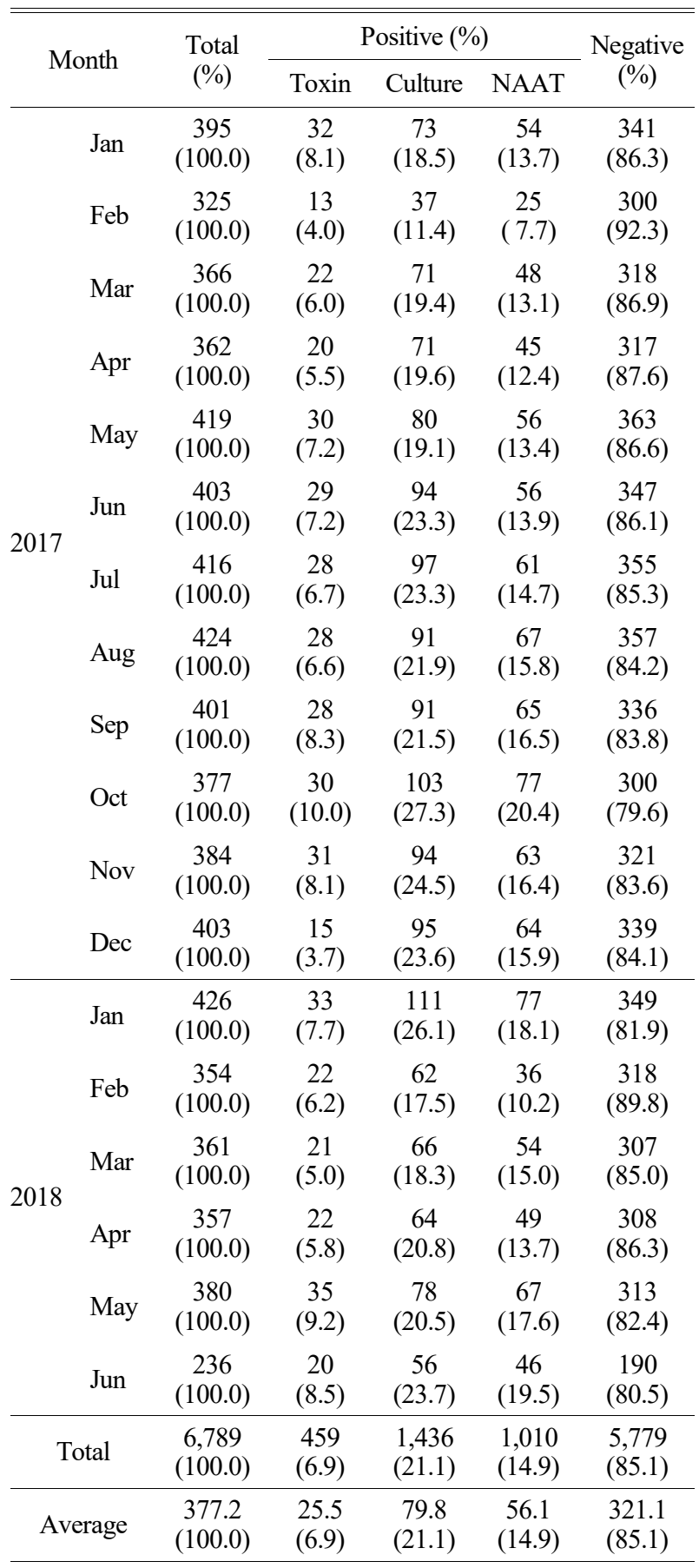

영동을 통해 결과를 확인하였다.

\section{C. difficile $\mathrm{GDH} \&$ Toxin 검사}

신속 멤브레인 효소면역측정법을 이용한 GDH \& Toxin 검 샤: 제조사의 지침에 따라 희석액과 콘쥬게이트(conjugate)
용액의 혼합액을 만들고, 환자 검체를 $25 \mu \mathrm{L}$ 첨가하였다. 검체-희석액-콘쥬게이트 혼합물 $500 \mu \mathrm{L}$ 을 검사용 디바이 스의 검체 주입구(sample well)에 주입하고 실온에서 15 분 간 반응시키고, 세척액을 반응 창(reaction window)에 분주 한 후 기질액(substrate)을 떨어뜨려 10 분 후 발색 결과를 판독하였다.

Illumigene을 이용한 C. difficile의 검출: Illumigene (Meridian, Bioscience, USA) 검사는 C. difficile의 독소 유전자 발현 부위를 직접 검출하는 검사로 양성의 판정은 분석 종말점(endpoint)에서 광전송(light transmission)의 변화를 측 정하여 산출된 값을 이용하며, 산출된 $\mathrm{Sf}$ (signal final)와 $\mathrm{Si}$ (signal initial)의 비율이 $90 \%$ 미만일 경우 양성으로 판정하 고, $90 \%$ 이상일 경우 음성으로 판정하였다.

\section{결 과}

\section{C. difficile 검사 방법에 따른 결과}

C. difficile의 독소와 배양 검사 양성률: C. difficile 독소와 배양 검사 총 6,789 건 중 독소 양성은 월평균 25.5 건(6.9\%), 배양 양성 79.8 건(21.1\%), 핵산증폭 법 양성 56.1건(14.9\%) 으로 나타났다(Table 1).

C. difficile의 GDH \& Toxin 검사 양성률: 2018년 6월 $\mathrm{GDH} \&$ Toxin 검사 총 152 건 중 $\mathrm{GDH}$ 항원 양성 33 건 (21.7\%), 독소 양성 8건(5.3\%), 이 중 $\mathrm{GDH}$ 항원 검사 양성 이었으며, 독소 검사 음성인 검체는 Toxigenic C. difficile을 확인하기 위해 Illuminazene 검사를 실시하여 양성은 10 건 (6.6\%)을 나타냈다. 7월은 총 381 건 중 $\mathrm{GDH}$ 항원 검사 양 성 76건(19.6\%), 독소 검사 양성 21건(5.5\%), Illuminazene 검사 양성 20 건(5.2\%), 8 월은 총 232건 중 $\mathrm{GDH}$ 항원 양성 55 건(23.7\%), 독소 양성 17 건(7.3\%), Illuminazene 검사 양성 16건(5.9\%)을 나타냈다(Table 2).

C. difficile 검사법의 민감도와 특이도 비교: 독소와 배양 (TC) 검사, $\mathrm{GDH} \&$ Toxin $(\mathrm{GDT})$ 검사 중 독소 검사에 대한 민감도와 특이도를 배양 검사의 양성 결과를 기준으로 구 하였다.

$\mathrm{TC}$ 검사의 민감도와 특이도는 각각 $30.8 \%, 99.5 \%(95 \%$ 신뢰구간)를 나타냈으며, $\mathrm{GDT}$ 검사에서는 각각 $56.1 \%$, $100 \%(95 \%$ 신뢰구간)를 나타내어 $\mathrm{GDT}$ 검사가 $\mathrm{TC}$ 검사가 민감도 $25.3 \%$, 특이도 $0.5 \%$ 로 높았다(Table 3 , Table 4). 
Table 2. The monthly positive rate distribution for GDH, toxin test and Illuminazene test of $C$. difficile

\begin{tabular}{|c|c|c|c|c|c|c|}
\hline & \multirow{2}{*}{ Month } & \multirow{2}{*}{ Total (\%) } & \multicolumn{3}{|c|}{ Positive (\%) } & \multirow{2}{*}{ Negative (\%) } \\
\hline & & & GDH & Toxin & Illuminazene & \\
\hline \multirow{3}{*}{2018} & Apr & $152(100.0)$ & $33(21.7)$ & $8(5.3)$ & $10(6.6)$ & $119(78.3)$ \\
\hline & May & $381(100.0)$ & $76(19.6)$ & $21(5.5)$ & $20(5.2)$ & $305(80.1)$ \\
\hline & Jun & $232(100.0)$ & $55(23.7)$ & $17(7.3)$ & $16(6.9)$ & $177(76.3)$ \\
\hline & $1(\%)$ & $765(100.0)$ & $164(21.4)$ & $46(6.0)$ & $46(6.0)$ & $601(78.6)$ \\
\hline
\end{tabular}

Table 3. Sensitivity and specificity of toxin test measured based on culture results in toxin and culture of $C$. difficile

\begin{tabular}{llccccc}
\hline \hline & & \multicolumn{2}{c}{ C. difficile culture } & & Sensitivity \\
& & & Positive $(\mathrm{N}=1,436)$ & Negative $(\mathrm{N}=5,352)$ & & $\begin{array}{c}\text { Specificity } \\
(95 \% \mathrm{CI})\end{array}$ \\
\cline { 3 - 5 } Toxin A \& B & Positive & 442 & 25 & 30.8 & 99.5 \\
& Negative & 994 & 5,327 & & \\
\hline
\end{tabular}

Sensitivity Confidence interval (CI): $28.45 \sim 33.22$

Specificity Confidence interval (CI): 99.31 99.68

Table 4. Sensitivity and specificity of toxin test measured based on GDH results in GDH \& toxin test of C. difficile

\begin{tabular}{|c|c|c|c|c|c|}
\hline & & \multicolumn{2}{|c|}{ C. difficile culture } & \multirow{2}{*}{$\begin{array}{c}\text { Sensitivity } \\
(95 \% \mathrm{CI})\end{array}$} & \multirow{2}{*}{$\begin{array}{l}\text { Specificity } \\
(95 \% \mathrm{CI})\end{array}$} \\
\hline & & Positive ( $N=164)$ & Negative $(\mathrm{N}=601)$ & & \\
\hline \multirow{2}{*}{ Toxin A \& B } & Positive & 92 & 0 & \multirow{2}{*}{56.1} & \multirow{2}{*}{100.0} \\
\hline & Negative & 72 & 601 & & \\
\hline
\end{tabular}

Sensitivity Confidence interval (CI): 48.45 63.47

Specificity Confidence interval (CI): 99.36 100.0

Table 5. Comparison of toxin test, culture test and GDH \& toxin test for diagnosis of toxige nic $C$. difficile infection

\begin{tabular}{lccc}
\hline \hline \multicolumn{1}{c}{ Method } & Positive (\%) & Negative (\%) & Total (\%) \\
\hline Toxin and & 1,010 & 5,779 & 6,789 \\
culture & $(14.9)$ & $(85.1)$ & $(100.0)$ \\
\multirow{2}{*}{ GDH \& Toxin } & 92 & 673 & 765 \\
& $(12.0)$ & $(88.0)$ & $(100.0)$ \\
\hline \multirow{2}{*}{ Total (\%) } & 1,102 & 6,452 & 7,554 \\
& $(14.6)$ & $(85.4)$ & $(100.0)$ \\
\hline
\end{tabular}

\section{Toxigenic $C$. difficile 검사 양성률 비교 분석}

C. difficile 검사 결과: 2017년 1월 1일부터 2018년 8월 17 일까지 $\mathrm{CDI}$ 진단을 위해 의뢰된 검사는 총 7,554 건 중 독소와 배양 검사 6,789 건으로 양성 1,010 건(14.9\%)이었으 며, $\mathrm{GDH} \&$ Toxin 검사는 765건으로 양성 92 건(12.0\%)이었 다(Table 5).
월별 C. difficile 검사 양성률: 독소와 배양 검사는 월평균 약 377건 검사했으며, toxigenic $C$. difficile 검사 양성은 월 평균 56.1건(14.9\%)이었다. 양성이 가장 높은 달은 2017년 10월 77건(20.4\%), 2018년 1월 77건(18.1\%) 순이었고, 가장 낮은 달은 2017년 2월로 25건(7.7\%)이었다.

$\mathrm{GDH} \&$ Toxin 검사는 IRB 승인 시점으로 제한되어 있 기 때문에 비교가 어렵지만 한 달 검사 자료가 모두 있는 2018년 7월의 자료에서는 독소와 배양 검사의 평균 의뢰 건수와 비슷한 381 건이 의뢰되었고 양성은 41 건(10.8\%) 이었다(Table 6).

진료과별 C. difficile 검사 양성률: 진료과별 C. difficile 검 사 양성률은 독소와 배양 검사에서 혈액종양내과(Hematooncology medicine) 240건(23.8\%), 응급실(Emergency room) 142건(14.1\%), 일반외과(General Surgery) 92건(9.1\%), 소화 기 내과(Gastroenterolo gy Internal Medicine) 89건(8.8\%) 순 으로 나타났다. 
Table 6. Monthly positive rate of GDH \& toxin test for diagnosis of $C$. difficile infection

\begin{tabular}{ccccc}
\hline \hline Month & $\begin{array}{c}\text { Positive } \\
(\%)\end{array}$ & $\begin{array}{c}\text { Negative } \\
(\%)\end{array}$ & $\begin{array}{c}\text { Total } \\
(\%)\end{array}$ \\
\hline \multirow{2}{*}{2018} & Jun & $18(11.8)$ & $134(88.2)$ & $152(100.0)$ \\
& Jul & $41(10.8)$ & $340(89.2)$ & $381(100.0)$ \\
& Aug & $33(14.2)$ & $199(85.8)$ & $232(100.0)$ \\
\hline \multicolumn{2}{c}{ Total (\%) } & $92(12.0)$ & $673(88.0)$ & $765(100.0)$ \\
\hline \multicolumn{2}{c}{ Average (\%) } & $30.7(12.0)$ & $224.3(88.0)$ & $255(100.0)$ \\
\hline
\end{tabular}

$\mathrm{GDH} \&$ toxin 검사에서는 혈액종양내과(Hematooncology medicine) 25건(27.2\%), 소아청소년과(Department of Pediatrics) 14 건(15.2\%), 신장 내과(Nephro logy Internal Medicine) 9건(9.8\%) 순으로 나타났다(Table 7).

C. difficile 검사법 검사 소요 시간 비교: 2018년 6월 17일 이전까지는 독소와 배양 검사를 하였으며, 2018년 6월 18 일부터는 $\mathrm{GDH} \&$ Toxin 검사로 변경 시행하였다. $C$. difficile 검사 변화에 따른 검사 소요 시간의 차이를 비교 분석하였다. 독소와 배양 검사 결과 음성으로 보고된 검 사 소요 시간은 평균 83.6시간이었으며, $\mathrm{GDH} \&$ toxin 검사 결과 음성으로 보고된 검사 소요 시간은 평균 11.2 시간으 로 약 3 일 빠른 결과를 나타냈다.

독소와 배양 검사에서 양성으로 보고된 검사 소요 시 간은 평균 140.7 시간이었고, GDH \& Toxin 검사에서 양성 으로 보고된 검사 소요 시간은 평균 12.1 시간이 소요되어 약 6일 빠른 결과 보고를 하였다(Fig. 1).

\section{고 찰}

C. difficile은 항생제 연관 설사(antibiotic-associated diarrhea, $\mathrm{AAD}$ )를 일으키는 대표적인 원인 균이며, 병원에서는 접 촉 주의 감염으로 분리하여 관리하고, 독소 생성능이 있 는 C. difficile은 병원성을 일으킨다(Hensgens et al., 2012).

C. difficile infection (CDI)를 효과적으로 치료하기 위해서 는 임상 및 검사의 근거에 기초한 신속한 진단과 설사 증상이 있는 환자에 대하여 검사를 진행해서 진단을 받 는 것이 중요하고, $\mathrm{CDI}$ 진단은 환자의 대변에서 독소를 생성하는 C. difficile을 동정하거나 C. difficile 독소를 검출 해야 한다(Oldfield et al., 2014). 또한 CDI 과잉진단으로 인한 치료로 불필요한 항생제를 투여받는 것이 환자에게 위험한 결과를 낳을 수 있기 때문에 신속하고 정확한 진
Table 7. Distribution of positive results for diagnosis of $C$. difficile by clinical department

\begin{tabular}{|c|c|c|}
\hline Clinical department & $\mathrm{TC}^{1}(\%)$ & $\mathrm{GDT}^{2}(\%)$ \\
\hline Hematooncology medicine (IM6) & $240(23.8)$ & $25(27.2)$ \\
\hline Emergency room (ER) & $142(14.1)$ & $7(7.6)$ \\
\hline General Surgery (GS) & $92(9.1)$ & $5(5.4)$ \\
\hline $\begin{array}{l}\text { Gastroenterology Internal Medicine } \\
\text { (IM1) }\end{array}$ & $89(8.8)$ & $4(4.3)$ \\
\hline Department of Pediatrics (PED) & $80(7.9)$ & $14(15.2)$ \\
\hline Cardiology Internal Medicine (IM2) & $67(6.6)$ & $8(8.7)$ \\
\hline Respiratory Medicine (IM3) & $42(4.2)$ & $1(1.1)$ \\
\hline Cancer Hospital (CCM) & $41(4.1)$ & $4(4.3)$ \\
\hline Neurosurgery (NS) & $39(3.9)$ & - \\
\hline Nephrology Internal Medicine (IM5) & $31(3.1)$ & $9(9.8)$ \\
\hline Thoracic surgery (TS) & $30(3.0)$ & $3(3.3)$ \\
\hline Infection Internal Medicine (IM7) & $29(2.9)$ & $5(5.4)$ \\
\hline $\begin{array}{l}\text { Department of Rehabilitation } \\
\text { Medicine (REH) }\end{array}$ & $28(2.8)$ & $1(1.1)$ \\
\hline Obstetrics and gynecology (OBGY) & $22(2.2)$ & $6(6.5)$ \\
\hline Neurology (NR) & $17(1.7)$ & - \\
\hline Orthopedics (OS) & $13(1.3)$ & - \\
\hline Urology (URO) & $3(0.3)$ & - \\
\hline Plastic Surgery (PS) & $2(0.2)$ & - \\
\hline $\begin{array}{l}\text { Endocrinology Internal Medicine } \\
\text { (IM4) }\end{array}$ & $1(0.1)$ & - \\
\hline $\begin{array}{l}\text { Rheumatology Internal Medicine } \\
\text { (IM9) }\end{array}$ & $1(0.1)$ & - \\
\hline Department of Family Medicine (FM) & $1(0.1)$ & - \\
\hline Total (\%) & $\begin{array}{l}1,010 \\
(100.0)\end{array}$ & $\begin{array}{c}92 \\
(100.0)\end{array}$ \\
\hline
\end{tabular}

$(\mathrm{N}=7,554)$

$\mathrm{TC}^{1}$ : toxin and culture test

GDT $^{2}$ : GDH \& toxin test

단이 무엇보다 필요하다(Polage et al., 2015).

이러한 $\mathrm{CDI}$ 는 고령 환자, 항생제 사용 환자, 입원 환자 에게 높은 감염률을 보이는 것으로 보고되었는데, 본 연 구의 결과 61세 이상 환자에서 양성은 C. difficile 독소와 배양(TC) 검사 497건(49.2\%), C. difficile GDH \& Toxin (GDT) 검사 45 건(48.9\%)을 나타냈고, 51세 이상 환자에서 양성은 $\mathrm{TC}$ 검사 707 건(70.0\%), GDT 검사 58건(63.0\%)이었다. $\mathrm{CDI}$ 진단 검사 양성 환자 중 입원 환자의 비율은 $\mathrm{TC}$ 검사 815 건(80.7\%), GDT 검사 80 건(87.0\%)을 나타냈는데, Jeon 등의 연구의 결과와 유사했다(Jeon, 2016).

배양 검사에서 C. difficile 양성률이 평균 $21.1 \%$ 에 비해 toxigenic $C$. difficile 양성률 $14.9 \%$ 보다 높게 나온 것은 독 


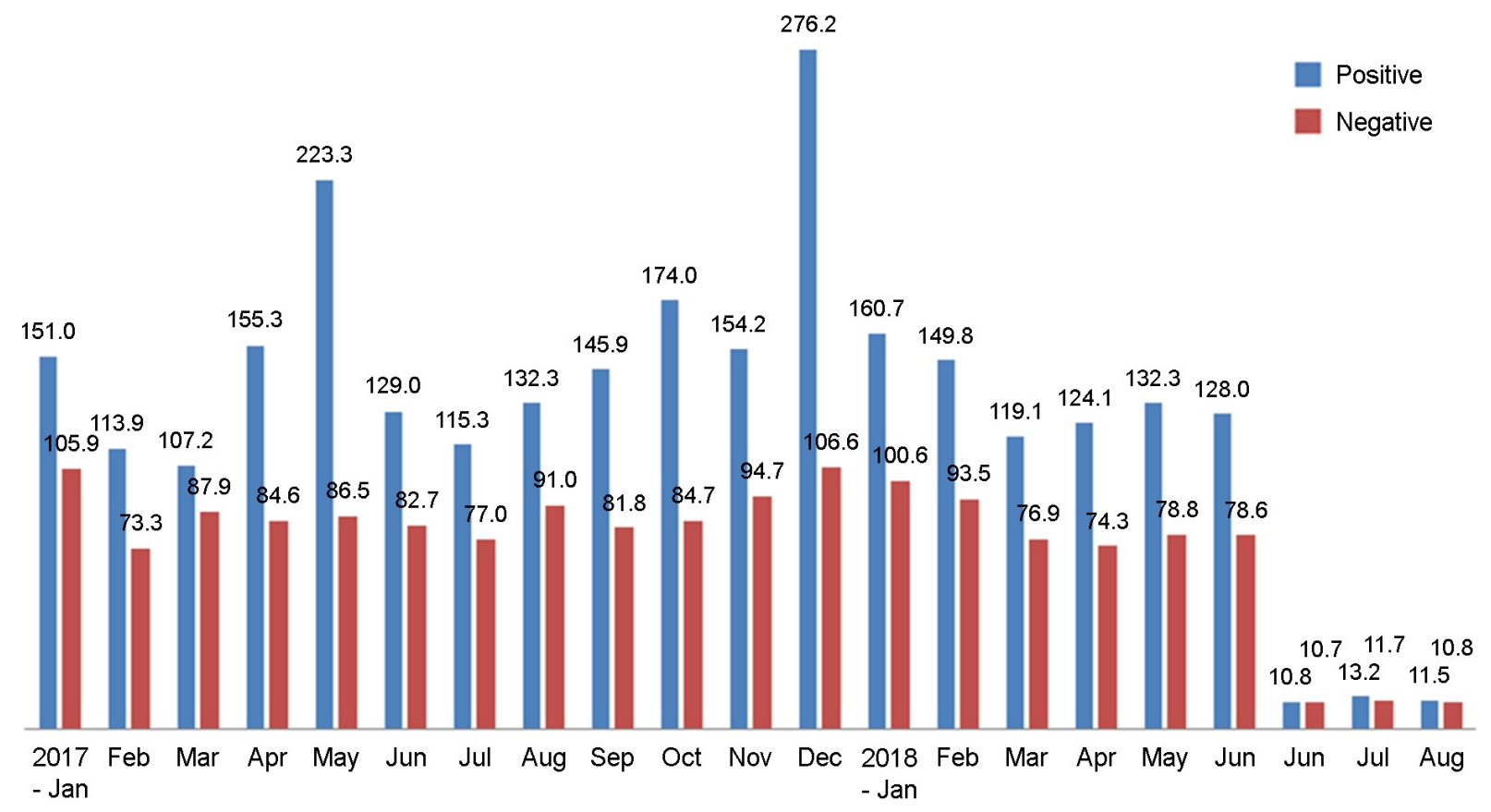

Fig. 1. Monthly average test turnaround time for diagnosis of $C$. difficile infection

소를 생성하지 않는 균주를 감별하지 못하여, 추가적으로 독소 검출 검사가 요구되는 단점을 시사하며, 정상인에게 도 2 5\% 정도 C. difficile이 존재한다는 Jumaa 등의 연구 결과와 일치한다(Jumaa et al., 1996).

$\mathrm{TC}$ 검사에서의 독소 검사는 enzyme immunoassay 원리 를 이용하는 검사로 검사 소요 시간이 짧고 검사법이 편 리하지만, 민감도 및 양성률이 낮기 때문에 $\mathrm{TC}$ 검사 평 균 양성률 $14.9 \%$, 독소 검사 평균 양성률 $6.9 \%$ 를 나타내 는 연구 결과에 따른 낮은 민감도를 보완하기 위해 핵산 증폭 법을 추가로 시행하여 toxigenic C. difficile을 감별하 고 있다. 이는 2010년 미국 미생물학회(American Society for Microbiology, ASM)의 guideline에서도 확인할 수 있는 데, ASM에서는 EIA 법 단독으로 toxigenic C. difficile을 진 단하는 것은 적합하지 않은 것으로 권고하고 있는 것과 일치하고, 그 가이드라인에서는 세 가지 알고리즘을 권고 하고 있는데, 그 중 첫 번째는 $\mathrm{GDH}$ 항원을 1차적으로 검사하여 음성이 나오면 더 이상의 검사는 진행하지 않고 음성으로 진단하며, 양성이 나올 경우에는 추가적인 독소 검출 법을 시행하여야 한다고 되어있다. 두 번째 알고리 즘은 $\mathrm{GDH}$ 항원과 독소를 동시에 검사하여 두 가지 모두 양성이 나올 시 Toxigenic C. difficile로 진단하며, GDH 항 원과 독소 중 한 가지만 양성으로 나올 시에는 핵산증폭
법 또는 배양 검사를 추가 시행하도록 되어 있다. 세 번째 알고리즘은 PCR 검사 단독으로 toxin을 검출하는 방법이 다. $\mathrm{ASM}$ 에서는 이러한 세 가지 알고리즘을 추천하고 있 다(Surawicz et al., 2013).

본 연구에서는 $\mathrm{GDT}$ 검사와 $\mathrm{TC}$ 검사의 민감도, 특이도 비교 및 결과 비교, 그리고 평균 검사 소요 시간 등을 분 석하여 $\mathrm{GDT}$ 검사가 $\mathrm{TC}$ 검사보다 민감도 $25.3 \%$, 특이도 $0.5 \%$ 더 높았고, $\mathrm{GDT}$ 검사 평균 검시 소요 시간도 음성 보고 기준으로 $\mathrm{TC}$ 검사보다 약 3 일 빠른 검사 소요 시간 을 통해 신속한 검사임을 확인하였다.

본 연구 결과 자료를 통한 $\mathrm{GDH} \&$ Toxin (GDT) 검사 및 llumigene (Meridian, Bioscience, USA) 검사로 진행된 CDI 진단 검사법은 신속 정확한 검사임을 확인하였다. $\mathrm{CDI}$ 진 단을 위해 환자의 검체가 검사실에 도착하면 짧게는 3시 간에서 평균 11 시간 정도의 검사 시간이 소요되기 때문에 $\mathrm{CDI}$ 진단이 지연되어 초기 설사 환자 치료 지연 및 원내 C. difficile 접촉 감염 전파로 인한 환자의 재원 기간 증가, 의료비용 중가 등을 예방하는 효과가 있을 것으로 사료 된다.

본 연구에서의 제한점은 $\mathrm{GDH} \&$ toxin $(\mathrm{GDT})$ 검사에서 도 독소 검사에 대한 부분은 민감도가 낮아서, $\mathrm{GDH}$ 항 원 양성, 독소 음성인 것은 반드시 추가 검사인 llumigene 
(Meridian, Bioscience, USA) 검사 등을 시행하여 확인하는 것이 필요하다고 생각된다. 비록 연구 자료가 IRB 승인 시점으로 제한되어서 자료의 양이 기존 검사와 비교하여 약 $10 \%$ 정도의 자료에 불과하지만 C. difficile 양성 환자 의 특성과 실험에 소요되는 평균 시간을 비교한 유용성 평가를 통해 Toxigenic C. difficile의 신속하게 진단 함으로 서 원내 감염의 확산을 방지하고 정확하고 신속한 진단과 환자의 고통을 줄이고 의료비용의 절감을 이루는데 참고 할 자료가 될 것으로 사료된다.

\section{ACKNOWLEDGEMENT}

None.

\section{CONFLICT OF INTEREST}

The authors have declared no conflict of interest

\section{REFERENCES}

Bartlett JG. Antibiotic-associated diarrhea. N Engl J Med. 2002. 346: 334-339.

Cho HJ, Ryoo E, Sun YH, Cho KH, Son DW, Tchah H. Epidemiology and Clinical Characterist ics of Clostridium difficileassociated diarrhea in Children: Comparison between Community And hospital-acquired Infection. Kjpgn. 2010. 13: 146 $-153$.

Dubberke ER, Olsen MA. Burden of Clostridium difficile on the healthcare system. Clin Infect Dis. 2012. 55: 88-92.

Hensgens MP, et al. "Clostridium difficile infection in the commnity: a zoonotic disease?". Clin Microbiol Infect. 2012.18: 635-645.

Jeon SR. Clinical Characterization of Clostridium difficile Infection in Elderly Patients. Korean J Gastroenterol. 2016. 67: 61-63.

Jumaa P, Wren B, Tabaqchali S. Epidemiology and typing of Clostridium difficile. European Journal of Gastroenterology \&
Hepatology. 1996. 8: 1035-1040.

Kelly CP, LaMont JT. Clostridium difficile - more difficult than ever. The New England Journal of Medicine. 2008. 359: 1932-1940.

Lo Vecchio A, Zacur GM. Clostridium difficile infection: an update on epidemiology, risk factors, and therapeutic options. Curr Opin Gastroenterol. 2012. 28: 1-9.

Morris AM, Jobe BA, Stoney M, Sheppard BC, Deveney CW, Deveney KE. Clostridium difficile colitis: an increasingly aggressive iatrogenic disease? Archives of surgery (Chicago, Ill: 1960). 2002. 137: 1096-1100.

Oldfield EC, Oldfield EC, Johnson DA. Clinical update for the diagnosis an d treatment of Clostridium difficile infection. World J Gastrointest Ph armacol Ther. 2014. 5: 1-26.

Park HS, Han DS. Management of Antibiotics-Associated Diarrhea. Korean J Gastroenterol. 2009. 54: 5-12.

Polage CR, Gyorke CE, Kennedy MA, Leslie JL, Chin DL, Wang $\mathrm{S}$, et al. Overdiagnosis of Clostridium difficile Infection in the Molecular Test Era. JAMA Internal Medicine. 2015. 175 1792-1801.

Poxton IR, McCoubrey J, Blair G. The pathogenicity of Clostridiu difficile. ClinMicrobiol Infect. 2001. 7: 421-427.

Surawicz CM, Brandt LJ, Binion DG, Ananthakrishnan AN, Curry $\mathrm{SR}$, et al. Guidelines for diagnosis, treatment, and prevention of Clostridium difficile infections. American Journal of Gastroenterology. 2013. 108: 478-498.

https://doi.org/10.15616/BSL.2020.26.3.210

Cite this article as: Joo HJ, Kim SH, Kwon PS, Ryu JK, Yook KD, Yu YB, Kim YK. Evaluation of the Usefulness of GDH \& Toxin Test for the Diagnosis of Clostridioides difficile in a Tertiary Hospital in Seoul. Biomedical Science Letters. 2020. 26: 210-216. 